1 Ramsay LE. Impact of venography on the diagnosis and management of deep vein thrombosis. Br Med f 1983;286:698-9.

2 Windebank WJ. Diagnosing pulmonary thromboembolism. Br Med f 1987;294:1369.

3 Decousus HA, Croze M, Levi FA, et al. Circadian changes in anticoagulant effect of heparin infused at constant rate. $\mathrm{Br} \mathrm{Med} \mathrm{F}$ 1985;290:341-4.

4 Wessler S, Morris LE. Studies in intravascular coagulation. IV. The effect of heparin and dicumarol on serum-induced venous thrombosis. Circulation 1955;12:533-56.

5 Basu D, Gallus A, Hirsh J, Gade J. A prospective study of the value of monitoring heparin treatment with the activated partial thromboplastin time. $N$ Engl J Med 1972;287:324-7.

6 Hull RD, Raskob GE, Hirsh J, et al. Continuous intravenous heparin compared with intermitten subcutaneous heparin in the initial treatment of proximal vein thrombosis. $N$ Engl $\mathcal{O} \mathrm{Med}$ 1986;315:1109-14.

7 Porter J, Hershel J. Drug related deaths among medical inpatients. FAMA 1977;237:879-81.

8 Landefeld CS, Cook EF, Flatley M, Weisberg M, Goldman L. Identification and preliminary validation of prediction of major bleeding in hospitalised patients starting anticoagulant therapy. Am f Med 1987;82:703-13.

9 Fennerty AG, Thomas P, Backhouse G, Bentley DP, Campbell IA, Routledge PA. Audit of heparin control. Br Med f 1985;290:27-8.

10 Fennerty AG, Renowden S, Scolding W, Bentley DP, Campbell IA, Routledge PA. Guidelines to control heparin treatment. Br Med f 1986;292:579-80.

11 Salzman EW, Deykin D, Shapiro RM, Rosenberg R. Management of heparin therapy. Controlled prospective trial. $N$ Engl f Med 1975;292:1046-50.

12 Glazier RC, Crowell EB. Randomised prospective trial of continuous vs intermittent heparin therapy. JAMA 1976;263:1365-7.

13 Wilson JE, Bynum LJ, Parkey RW. Heparin therapy in venous thromboembolism. Am $\mathcal{f}$ Med $1981 ; 70: 808-16$

14 Bentley PG, Kakkar VV, Scully MF, et al. An objective study of alternative methods of heparin administration. Thromb Res 1980;18:177-87.

15 Walker MG, Shaw JW, Thomson GJL, Cumming JGR, Thomas ML. Subcutaneous calcium heparin versus intravenous sodium heparin in treatment of established acute deep venous thrombosis of the legs: a multicentre prospective randomised trial. Br Med f 1987;294:1189-92.

16 Doyle DJ, Turpie AGG, Hirsh J, et al. Adjusted subcutaneous heparin or continuous intravenous heparin in patients with acute deep venous thrombosis. Ann Intern Med 1987;107:441-5.

17 Scolding NJ, Routledge PA. Heparin and deep vein thrombosis. Ann Intern Med 1988;108:488.

18 Law J, Biggs JC. Comparative plasma heparin levels after subcutaneous sodium and calcium heparin. Thromb Haemost 1978;40:497-506.

19 Carey LC, Williams RD. Comparative effects of dicoumarol, Tromexan, and heparin on thrombus propagation. Ann Surg 1960;152:919-22.

20 Gallus A, Jackman J, Tillet J, Mills W, Wycherley A. Safety and efficacy of warfarin started early after submassive venous thrombosis or pulmonary embolism. Lancet 1986;ii:1293-6.

21 Bell WR, Tomaswo PA, Alving BM, Duffy TP. Thrombocytopenia occurring during the administration of heparin. A prospective study in 52 patients. Ann Intern Med 1976;85:155-60.

22 Hull R, Delmore T, Genton E, et al. Warfarin sodium versus low-dose heparin in the long term treatment of venous thrombosis. $N$ Engl f Med 1979;301:855-8.
23 Lagerstedt CL, Olsson CG, Fagher BO, Öqvist BW, Albrechtsson U. Need for long term anticoagulant treatment in symptomatic calf vein thrombosis. Lancet 1985;ii:515-8.

Poller L. Laboratory control of oral anticoagulants. Br Med f 1987;294:1184.

25 Hull R, Hirsh J, Jay R, et al. Different intensities of oral anticoagulant therapy in the treatment of proximal vein thrombosis. N Engl F Med 1982;307:1676-81.

26 Loeliger EA, Van Dijk-Wierda CA, Van Den Besselaar AMHP, Broekmans AW, Roos J. Anticoagulant control and the risk of bleeding: In: Meade TW, ed. Anticoagulants and myocardial infarction: a reappraisal. Chichester: Wiley, 1984:135-77.

27 Fennerty A, Dolben J, Thomas P, et al. Flexible induction dose regimen for warfarin and prediction of maintenance dose. $\mathrm{Br}$ Med $\mathcal{f}$ 1984;288:1268-70.

28 Thomas P, Fennerty A, Backhouse G, Bentley DP, Campbell IA, Routledge PA. Monitoring ora anticoagulants during heparin therapy. Br Med $\mathcal{F}$ 1984;288:191

29 Anonymous. Treatment of deep vein thrombosis [Editorial]. Lancet 1962;ii:593-5.

30 Ruckley CV. Management of pulmonary embolism. Br Med f 1982:285:831-2.

31 Coon WW, Willis PW. Recurrence of venous thromboembolism. Surgery 1973;73:823-7.

32 Acheson L, Speizer FE, Tager I. Venous thrombosis: duration of anticoagulant therapy. $N$ Englf Med 1975;293:879.

33 Petiti OB, Strom BL, Melmon KC. Duration of warfarin anticoagulant therapy and the probabilities of recurrent thromboembolism and hemorrhage. Am f Med 1986;81:255-9.

34 O'Sullivan EF. Duration of anticoagulant therapy in venous thromboembolism. Med $\mathcal{J}$ Aust 1972;ii:1104-7.

35 Fennerty AG, Dolben J, Thomas P, et al. A comparison of 3 and 6 weeks anticoagulation in the treatment of venous thromboembolism. Clin Lab Haematol 1987;9:17-21.

36 Holmgren K, Anderson G, Fagrell B, et al. One month versus six months therapy with ora anticoagulants after symptomatic deep vein thrombosis. Acta Med Scand 1985;218:279-84.

37 Levine MN, Raskob G, Hirsh J. Risk of haemorrhage associated with long term anticoagulant therapy. Drugs 1985;30:444-60

38 Miller GAH, Sutton GC, Kerr IH, Gibson RV, Honey M. Comparison of streptokinase and heparin in the treatment of isolated acute massive pulmonary embolism. Br Med f 1971;ii:681-4.

39 Hall R. Difficulties in the treatment of acute pulmonary embolism. Thorax 1985;40:729-33.

40 Goldhaber SZ, Vaughan DE, Markis JE, et al. Acute pulmonary embolism treated with tissue plasminogen activator. Lancet 1986;ii:886-8.

\section{Correction}

\section{Aspirin for strokes and transient ischaemic attacks}

An author's error occurred in Dr Peter Sandercock's editorial (22 October, p 995) In the third sentence of the penultimate paragraph the dose of aspirin being tested in the Swedish low dose aspirin trial is $75 \mathrm{mg}$, not $30 \mathrm{mg}$ as published.

\title{
INSTRUCTIONS TO AUTHORS
}

The BMF has agreed to accept manuscripts prepared in accordance with the Vancouver style (BMJ, 6 February 1988, p 401) and will consider any paper that conforms to the style. More detailed and specific instructions are given below.

The following include the minimum requirements for manuscripts submitted for publication.

All material submitted for publication is assumed to be submitted exclusively to the $B M F$ unless the contrary is stated.

Manuscripts will be acknowledged; letters will not be unless a stamped addressed envelope is enclosed.

Papers will normally be refereed and may be statistically assessed before acceptance.

Authors should give their names and initials, their posts at the time they did the work, and one degree or diploma. All authors must sign their consent to publication.

Three copies should be submitted. If the manuscript is rejected these will be shredded.

Typing should be on one side of the paper, with double spacing between the lines and $5 \mathrm{~cm}$ margins at the top and left hand side of the sheet.

Abbreviations should not be used in the text.

Drugs should be given their approved names, not their proprietary names, and the source of any new or experimental preparations should be given

SI units are used for scientific measurements, but blood pressure should continue to be expressed in $\mathrm{mm} \mathrm{Hg}$.
Statistical procedures should be described in the methods section or supported by references.

Tables and illustrations should be separate from the text of the paper. Tables should be simple and should not duplicate information in the text of the article.

Photographs should be trimmed to remove all redundant areas and should be no larger than $30 \times 21 \mathrm{~cm}$ (A4); the top should be marked on the back of each print.

Abstracts should accompany all original articles. They should be up to 150 words long and should set out what was done, the principal findings, and their implications.

References must be in the Vancouver style and their accuracy checked before submission. They should be numbered in the order in which they appear in the text. Each reference should include the names and initials of each author (or, if more than six, the first three followed by et $a l$ ), the title of the article, the title of the journal (abbreviated according to the style of Index Medicus), the year, the volume, and the first and last page numbers. References to books should give the names of any editors, the place of publication, the publisher, and the year.

Letters to the editor submitted for publication must be signed personally by all authors, who should include one degree or diploma.

The editor reserves the customary right to style and if necessary shorten material accepted for publication and to determine the priority and time of publication.

Detailed instructions are given in the $B M \mathcal{F}$ dated 2 January $1988, \mathrm{p} 48$. 